\title{
Quo vadis, logistica? ${ }^{\#}$
}

\author{
Petr Pernica*
}

\section{Úvod}

Pro realitu současné ekonomiky jsou př́značné změny související s přechodem od průmyslové éry k éře informatiky, s civilizační „třetí vlnou“ (Toffler, Tofflerová, 2001), jež se týká výrobních faktorů, nehmotných hodnot, demasifikace výroby a spotřeby, charakteru práce, inovací, měřítka, organizací, systémové integrace, infrastruktury a rychlosti. $\mathrm{Z}$ našeho úhlu pohledu těžiště změn spočívá v individualizaci produkce a v jejím přizpůsobení zákazníkům. Od „hlavního pelotonu“ odvětví účastnících se tohoto historicky jedinečného závodu, se odpoutávají odvětví charakterizovaná vysokou přidanou hodnotou a využíváním znalostí, agilitou a těsnou spoluprací, v nichž klesá význam hmotných zdrojů a aktiv, prostorových omezení, fyzických zprostředkovatelů a roste význam služeb přidávajících hodnotu, informací, času a nových forem obchodních transakcí (Křovák, 2002). Pro tato odvětví se logistika stává kritickým faktorem, a to $\mathrm{z}$ hlediska rychlosti a nákladů dodání, působení v neznámém prostředí, sledování zásilek a zajištění zpětných toků (Pernica, 2005). U úspěšných firem ve většině odvětví pozorujeme upevňování logistiky v pozici spolutvůrce podnikové strategie a narůstání významu supply chain managementu, řízení integrovaných hodnototvorných procesních řetězců, jež propojují podnik se zákazníky i s dodavateli a stávají se jedním z klíčových zdrojů konkurenční výhody.

Obsahem tohoto př́ispěvku je průzkum vývojových tendencí v logistice, jež logistiku staví do role katalyzátoru anebo limitujícího faktoru uvedených změn.

\section{Věci je třeba „dělat jinak“. Vyžaduje nová strategie také nové logistické technologie?}

- Individualizace vztahu k zákazníkům znamená změnu ve strategii logistiky i v metodice stanovení úrovně dodavatelských služeb. Perfektní dodávky musí být založené na včasnosti, úplnosti a bezchybnosti.

Dosud uživané metody stanovení úrovně logistických (dodavatelských) služeb poměrujíci náklady na dodání s vícenáklady a ztrátami, resp. logistické náklady s prínosem $k$ výši zisku, vycházely z pohledu na zákazníky jako na statistický soubor a dospívaly k souhrnnému procentnímu výsledku podílu bezchybných dodávek. S individualizovaným př́stupem $k$ zákazníkům jsou tyto metody zpochybňovány. Navrhuje se ,stupen̆ dosaženi perfektni dodávky" (Christopher, 2000) směrujíci $k$ uspokojeni každého zákazníka za všech okolností na $100 \%$.

\footnotetext{
Článek je zpracován jako jeden z výstupů výzkumného záměru VZ 61384309025 „Nová teorie ekonomiky a managementu a jejich adaptační procesy“ a interního grantu IGA VŠE v Praze IG 305016 „Analýza vhodnosti struktur a chování logistických řetězců v podmínkách přechodu k nové ekonomice“.

* Doc. Ing. Petr Pernica, CSc., vedoucí Katedry logistiky, Fakulta podnikohospodářská, Vysoká škola ekonomická v Praze.
} 
- Volba strategie firmy a jejího logistického systému je definována charakterem odvětví, v němž firma působí.

Logistický systém firmy má podporovat celkovou strategii firmy. V růstovém oboru je strategii aktivni vytvárení nových segmentù trhu a co nejrychlejší uspokojování zákazniků ,na míru“. Zralý obor vyžaduje přizpůsobivost změnám, pružnost, dosažitelnost na bázi spojenectví, partnerských vztahů a společných projektù. V upadajicím oboru je třeba snižovat náklady a zlepšovat kvalitu a služby. Zralé a upadající obory jsou katalyzátory rozvoje outsourcingu. K němu přispivá i turbulentní charakter trhu $s$ nemožností predikce a problematizováním strategického rozhodování. Potřeba rozložit riziko spojené s fungováním logistických řetězcư rovněž vede $k$ outsourcingu.

- Je třeba respektovat kauzalitu vývojových vztahů: zákazníci - objednávky - distribuce - výroba - doprava.

Zákazníci vyžadující individuálni př́stup, spolehlivost dodávek a perfektní informace, měni charakter objednávek směrem $k$ rüznorodosti a zakládaji prímé vztahy $k$ výrobcuim. Na tuto situaci musí distribuce reagovat různými formami, technologiemi a cestami, a to i pro jednoho a téhož zákazníka; pro jeden druh výrobku je třeba disponovat paralelními způsoby distribuce, reagovat pružně s minimálními zásobami. Výroba se musí charakteru distribuce přizpůsobit cestou flexibility a synchronizace, schopností expedovat $i$ velmi malá množství, kompletovat a konsolidovat a poskytovat služby přidávajíci hodnotu. Toto vše se promitá do rostoucího objemu prepravy, menšich a rozmanitějšsich zásilek, většsi frekvence zásilek a většiho podilu expresnich zásilek, rưstu přepravních vzdáleností a zvýšené multimodality $v$ dopravě. Vede to rovněž $k$ narưstajícím kongescím na dálniční a silniční siti.

- Logistické strategie se polarizují. Konkurence logistickými službami je silnou alternativou ke konkurenci cenou.

Přiklad obchodních společností může dobře posloužit jako ilustrace vazby mezi alternativni strategickou orientací na různé segmenty zákazniků, potřebným charakterem provozních jednotek maloobchodni sitě a způsobem prodeje, jež musí být podpořeny $v$ př́padě orientace na konkurenci prostřednictvím logistických služeb individualizovanými technologiemi při optimálnich logistických nákladech, anebo v prípadě orientace na konkurenci cenou co nejjednodǔšsimi, standardními logistickými technologiemi odpovídajícími průměrným logistickým službám při minimalizaci logistických nákladů. (Pernica, 2005)

- Nutnou podmínkou konkurenceschopnosti se stala vnitřní a vnější integrace logistických řetězců, provázená jejich restrukturalizací.

Již koncem 90. let 20. století mělo $90 \%$ nadnárodních společností restrukturalizováno své distribučni systémy s tím, že převažujícím usporádáním se stal systém s jedním distribučním centrem celoevropského dosahu. V důsledku toho společnosti dosáhly významného zkrácení dodacích lhůt: 60 \% produkce byly schopny dodávat do dvou dnü, z toho $30 \%$ následujicího dne po objednání a $8 \%$ téhož dne. Pro srovnání: evropští dodavatelé jako celek byli v téže době schopni dodávat $8 \%$ produkce do dvou týdnư, $18 \%$ do jednoho týdne, $34 \%$ do 2-4 dnù, $24 \%$ do 24 hodin a jen $4 \%$ týź den. Nadnárodni společnosti také z $80 \%$ restrukturalizovaly své výrobní procesy, pričemž $50 \%$ z nich redukovalo počet výrobnich závodĩ. Zkracováni dodacich lhůt při častějších dodávkách praktikovalo $90 \%$ nadnárodních společností. Polovina společností investovala do zlepšeni služeb zákazníkům a 67 \% společností vykázalo efekty, jež jim restrukturalizace přinesla (Pernica, 1998). 
- Významnou cestou ke zkrácení dodacích lhůt a ke zefektivnění je zjednodušení struktury logistických řetězců.

Potvrdily to autorem (Pernica, 1998, 2005) provedené modelové simulace di̊sledků změn ve struktuře obchodnich řetězců na dobu reakce a na logistické náklady. Simulován byl průtok zboží řetězcem (s vyloučením vlivu obrátky zásob a skladovaného zboži), a to ve variantách:

- skladových dodávek z jednoho provozního skladu (varianta 1),

- skladových dodávek ze skladové sitè s centrálni expedicí (varianta 2),

- skladových dodávek ze skladové sités rozvozem nezkompletovaného zboži (varianta 3),

- mimoskladových dodávek (př́mého rozvozu) (varianta 4),

- cross-dockingu (varianta 5).

Potřeba času byla zjištěna takováto:

- varianta $4 \ldots \ldots \ldots \ldots$........ 100,00\%

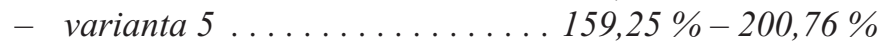

- varianta $1 \ldots \ldots \ldots \ldots . \ldots . \ldots 204,13 \%-245,65 \%$

- varianta $3 \ldots \ldots \ldots \ldots \ldots . \ldots 33,78 \%-375,30 \%$

- varianta $2 \ldots \ldots \ldots \ldots \ldots .431,61 \%-473,13 \%$

Tomu odpovídaji logistické náklady (tj. minimální výše ,nákladů na výkon “, jež tvoři cca $80 \%$ z celkových logistických nákladů u tohoto druhu retězců):

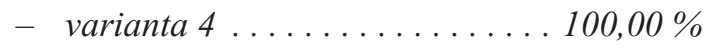

- varianta $5 \ldots \ldots \ldots \ldots . \ldots . \ldots 121,92 \%$

- varianta $1 \ldots \ldots \ldots \ldots . \ldots . \ldots 155,47 \%$

- varianta $3 \ldots . . . . . . . .4410,13 \%$

- varianta $2 \ldots . . . . . . . . . .439,23 \%$

Logistické retèzce s primými dodávkami (klasickými a přes cross-dockové centrum) jsou tedy nejvýhodnèjš́í.

- Uplatnění elektronické komunikace rovněž vede k získání konkurenční výhody.

Výhoda se dosahuje prostřednictvím zkráceni doby potřebné k vyrizování objednávek, snižení pracovní náročnosti a nákladì, omezení chybovosti a zvýšení flexibility. Potvrdily to modelové simulace provedené pomoci SW Aris na katedře logistiky ve spolupráci se společností IDS Scheer (Hanslićek, 2005). Simulovány byly procesy (tvorby požadavku, tvorby objednávky, př́jmu objednávky, zpracováni objednávky od zákazníka, objednání u výrobce, expedice, dodáni zákazníkovi, př́imu u zákazníka, likvidace faktur ad.) na variantách logistických řetězců s uplatnéním:

- obsluhy zákaznické firmy prostřednictvím obchodní společnosti (varianta 1),

- obsluhy konečného zákazníka prostřednictvím obchodni společnosti (varianta 2),

- nákupu maloobchodu u nezávislého velkoobchodu (varianta 3),

- zásobováni prodejny maloobchodu z vlastního distribučního centra objednávajícího u výrobce (varianta 4),

- primého zásobováni prodejny maloobchodu od výrobce (varianta 5),

- obsluhy zákaznické firmy prostřednictvím poskytovatele logistických služeb (varianta 6),

- přmího zásobování zákaznické firmy poskytovatelem logistických služeb, jenž přebirá roli obchodni společnosti (varianta7).

Simulacemi byla zjištěna úspora času v rámci jednotlivých variant při elektronické komunikaci uplatněné v maximálním dostupném rozsahu ve srovnání s tradičním způsobem komunikace v logistickém řetězci: 


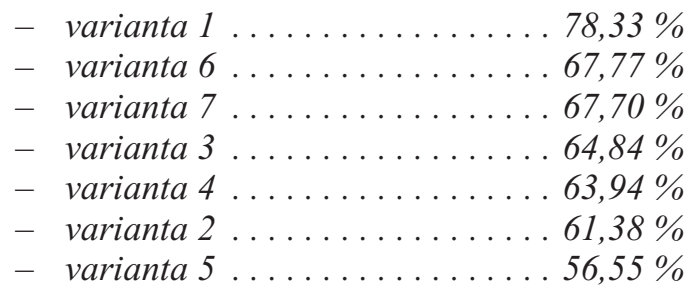

Úspora pracovníků s tím spojená je dosažitelná v rozsahu cca 43,86\% u zákaznické firmy, 93,33\% u obchodni společnosti, 23,15\% u poskytovatele logistických služeb a 66,66\% u výrobce.

\section{Jsou nákladové úspory stále tak důležité? Jakých efektů lze dosáhnout logistickým řešením?}

- Zkušenost automobilového průmyslu ř́ká, že logistická výkonnost a kvalita jsou důležitější než nákladové úspory. V logistice automobilového průmyslu jsou stále ještě dosažitelné efekty v řádu i desítek procent. Doba průběhu objednávky může být zkrácena z dnešních 40 dnů na 3-6 dnů.

Tř́letý program zeštíhlení zásobovacích systémů automobilových výrobců činných na území Velké Británie, uskutečněný v 90. letech ve spolupráci s majoritním ocelářským dodavatelem, dodavateli v 1. linii, průmyslovými distributory a s podporou britské vlády, dosáhl zkráceni dodacich lhuit o $40 \%$, snižení zásob o $30 \%$, zvýšeni kvality o $45 \%$ a nárůst produktivity o $15 \%$. V současné době probihajicí na něj navazujicí program (má být ukončen roku 2010) hodlá dosáhnout zkrácení celkové doby prủběhu objednávky z dnešních cca 40 dnů na 3 dny pro území britského souostroví, resp. 6 dnů pro kontinentálni Evropu, a to při $100 \%$ montáži vozủ BTO, zadáváni objednávek př́mo do montáže, zprůhlednění výroby a on-line spojení s dodavateli a LLP a při minimalizaci složitosti výroby. Ukazuje se chybnost dominance nákladových úspor, jež byla dosud uplatňována a potřeba nahradit ji stabilizací smluvních vztahů vedoucí ke zvýšeni logistické výkonnosti a kvality. Největši omezeni spočívá v ICT; překonat je lze ne dřive než za 6-10 let (Pernica, 2005).

- Úspěšné firmy uplatňují komplexní, systémová řešení logistických problémů a zapojují do nich i spolupracující subjekty vně firmy.

Pro většinu řešení je typické využití kombinace několika progresivních logistických technologií. Dominuje orientace na procesni stránku, provázená perfekcionalizací logistické infrastruktury. Potřebná pružnost je dosahována většinou spoluprací s externími poskytovateli logistických služeb, zrovna tak dalši cílové výkonové a kvalitativní parametry. Na pozadí provedených změn je snaha zlepšit služby zákazníkům (Pernica, 2005, 2006).

Sledovanými firmami jsou:

F1 The Bata Organization, Francie - výroba, distribuce a prodej obuvi,

F2 Bosch Siemens Hausgeräte GmbH, Německo - výroba elektrotechnického (,, bilého") spotřebniho zboži,

F3 Colgate - Palmolive UK, Velká Británie - výroba kosmetiky,

F4 Compaq Computer, USA/Nizozemsko, Francie, Velká Británie - výroba počitaču,

F5 DaimlerChrysler, Německo - výroba automobilů, 
F6 Dräger, Německo - výroba bezpečnostni techniky,

F7 Ford-Werk, Německo - výroba automobilü,

F8 Jaguar a další výrobci, Velká Británie - výroba automobilù,

F9 Londis, Velká Británie - maloobchod potravinami (obchodni skupina 2000 nezávislých vlastnikui),

F10 Microsoft, Irsko - produkce SW (operačních systémů, uživatelských aplikací, sitových produktů a $S W$ produktů) pro $P C$,

F11 Nortel Networks, Kanada - výroba a instalace telekomunikačnich zařizení,

F12 Otto Versand, Německo - zásilkový obchod,

F13 Rank Xerox Manufacturing B. V., Nizozemsko - výroba, opravy a renovace kopirovacich stroju,

F14 Siemens AG Medizinische Technik-Geschäftsgebiet Computerotomografie, Nèmecko - výroba a instalace počítačových tomografü.

Logistická strategie sledovaných firem spočivala:

- v řšení části logistického řetězce ............... u 21,43\% firem,

- v uceleném supply chain řešení ................. u 85,71\% firem,

- v řšeni jak materiálových, tak informačnich toki̊ ....... u 100,00\% firem,

- v zaměrení na logistickou infrastrukturu............. u 71,43\% firem,

- v zaměreni na logistické procesy................. u 100,00\% firem,

- v uplatnění hromadných logistických technologií....... . u 50,00\% firem,

- v uplatnění individualizovaných logistických technologii . . u 92,86\% firem,

- vinsourcingu logistiky......................... u 14,29\% firem,

- voutsourcingu logistiky celkem...... u 85,71\% firem,

z toho omezeného na dilč́ činnost,

resp. na článek řetězce . . . . . . . . . . . . . . . . . . u 21,43\% firem,

na úrovni $3 P L \ldots \ldots \ldots \ldots \ldots \ldots \ldots \ldots \ldots \ldots$. $28,57 \%$ firem,

na úrovni $4 P L \ldots \ldots \ldots \ldots \ldots \ldots \ldots \ldots \ldots \ldots \ldots$. $35,71 \%$ firem.

- Logistická řešení u úspěšných firem přinášejí efekty v řádu až několika desítek procent.

Jedná se o tyto kategorie efektů:

E1 - úspora nákladů, př́nos k zisku,

E21 - zvýšseni pružnosti, včasnosti,

E22 - zvýšení produktivity, výkonnosti,

E23 - redukce zásob,

E24 - zlepšení využití ploch, kapacit,

E25 - úspora pracovníkü,

E3 - zlepšení kvality, snižení chybovosti.

Konkrétni vyčislené efekty dosažené jednotlivými firmami jsou:

F1: E1 - 2. misto co do objemu prodeje ve Francii

- potřeba finančních prostředků nutných k produkci týchž hodnot: - $48 \%$

E22 - průběžná doba vývoje: $-98 \%$

E23 - zásoby: $-80 \%$

F2: E1 - úspora nákladů: 14 mil. EUR za rok

E21 - stupeň pohotovosti dodávky: $+18 \%$

E23 - doba obratu zásob: $-42 \%$

E24 - vytížení vozidel: $+14 \%$

E3 - chybovost: $0,063 \%$

(Projektu byla udělena německá logistická cena.) 
F3: E1 - náklady na distribuci: $-24 \%$

E21 - dodaci lhuity: $-50 \%$

- včasnost dodávek: $+25 \%$

F4: E1 - úspora z poklesu vázanosti aktiv v zásobách: 900 mil. USD

- náklady na distribuci: $-15 \%$

- náklady na skladování:-19\%

- roční výnosy: $+50 \%$

E21 - bezchybnost dodávek: $+26 \%$

- včasnost dodávek: $+30 \%$

- plánovací cyklus: $-84 \%$

E23 - zásoby: $-40 \%$

- doba obratu zásob: -50\%

- pokles vázanosti aktiv v zásobách: $-22 \%$

F5: E1 - úspora nákladù: $-10 \%$ až $-15 \%$

F6: E1 - výrazné zlepšeni hospodářského výsledku

E21 - dodržování termínu: $+35 \%$

- průběžná doba: $-71 \%$ až $-93 \%$

E22 - počet prodejnich položek: -68\%

- počet dilì: $-54 \%$

E23 - zásoby: $-24 \%$

E25 - počet pracovníku: $-21 \%$

(Projektu byla udělena némecká logistická cena.)

F7: E1 - pokles vázanosti aktiv v zásobách: -94\%

E22 - produktivita: $+24 \%$ (jedna z nejproduktivnějšich automobilek světa)

- počet dodavatelu: $-60 \%$

- počet dílů produkovaných závodem:-62\%

- JIT: $+39 \%$

- JIS: $+84 \%$

- Kanban: $+5 \%$

E23 - zásoby na montážní lince: $-92 \%$

(Pilotní- vzorový projekt v rámci koncernu. První montážní závod Fordu ve světě, kde důslednè uplatnèn pull princip. V rámci koncernu vedoucí postavení v produktivitě, týmové práci a rízení materiálových tokì.)

F8: E21 - dodaci lhuity:-40\% (Lean Processing Programme)

- celková prùběžná doba objednávky: -31 \% (Lean Processing Programme),

- $92 \%$ (3DayCar Programme)

E22 - produktivita: $+15 \%$ (Lean Processing Programme)

- rozsah vzájemného obchodováni: + $30 \%$

E3 - kvalita: $+45 \%$ (Lean Procesing Programme)

F9: E21 - úroveň služeb u dodavatelů: $+0,5 \%$, u Londis: $+3 \%$

- objednávkový cyklus: $-6 \%$

E23 - zásoby u dodavatelu: $-14 \%$, u Londis: $-10 \%$ až $-20 \%$

F10: E21 - dodaci lhĩty: $-95 \%$

E22 - množství zásilek: -84\%

E24 - počet regionálních skladů: $-100 \%$

- kapacita skladi: - $80 \%$

- počet prodejnich základen: $-75 \%$

F11: E1 - 2. nejrychleji rostouci firma v oboru - růst: $30 \%$ až $35 \%$ (rüst oboru: $20 \%$ ), bèhem 2 let $z$ 84. místa na 5. místo v oboru

F12: E1 - jednicové náklady: $-34 \%$

- náklady na pracovni sily: -52\% 
- náklady na distribuci:-79 mil. EUR za rok

E22 - produktivita ve skladech: $+27 \%$

- produktivita u sortimentu málo objemného zboži: $+48 \%$

(Projektu byla udělena německá logistická cena.)

F13: E1 - náklady na materiál:-40\%

- náklady na zásobovací přepravu: -40\%

- výrobni náklady: -50\%

- náklady na distribuci: $-40 \%$

E21 - včasnost dodávek: $+28 \%$

E22 - prủběžná doba montáže: -75\% až-80\%

E23 - zásoby materiálu: -60\%

- obrátka zásob: $+83 \%$

E24 - počet dodavatelu: $-90 \%$

E3 - kvalita materiálu: $+16 \%$

F14: E1 - ziskovost

- úspora nákladů: 1,8 mil. EUR za rok

E21 - dodaci lhůty: $-86 \%$

- spolehlivost dodávek: $+39 \%$

- zrychlení procesů: $+76 \%$

- průběžná doba výroby: -70\%

E22 - prínos produktivity: 23 mil. EUR $v 1$. roce

E23 - zásoby: $-40 \%$

E24 - využití výrobnich ploch: $+50 \%$

E3 - kvalita procesü: $+200 \%$

(Projektu byla udèlena cena Evropské logistické asociace, německá logistická

cena a cena ,Továrna roku“ " $v$ kategorii kusové a malosériové výroby

v Německu.)

- Současný konkurenční potenciál logistiky je srovnatelný s potenciálem, jenž byl firmami využit zhruba o 5-10 let dř́ive.

Tehdy šlo o efekty získané z logistických systémů první generace (logistika byla chápána jako funkce toku materiálu) a z náběhu logistických systémů druhé generace (logistika v pozici integrační funkce) u firem Toyota, Mazda, Ford, BMW, Audi, VW, Bosch, Osram, Siemens a dalších. Technologicky vzato šlo nejčastěji o uplatnění JIT.

Tab. č. 1: Porovnání dosažených efektů

\begin{tabular}{||l|r|r||}
\hline \multirow{2}{*}{\multicolumn{1}{|c|}{ OBLAST HODNOCENÍ }} & \multicolumn{2}{|c|}{ DOSAŽENÉ EFEKTY } \\
\cline { 2 - 3 } & DǨÍVE & \multicolumn{1}{c|}{ NYNÍ } \\
\hline \hline Nárůst produktivity & $20 \%-50 \%$ & $15 \%-48 \%$ \\
Redukce výrobních zásob & $50 \%-100 \%$ & $40 \%-92 \%$ \\
Redukce zásob hotových výrobků & $95 \%$ & $14 \%-40 \%$ \\
Úspora výrobních a skladových ploch & $40 \%-80 \%$ & $50 \%$ \\
\hline
\end{tabular}

Nynějš́ ř rešení jsou založena na plné integraci logistických systémů a jí odpovídajicich pokročilých technologiích, což vytváři zdroj růstu produktivity plně srovnatelný s jejím dřivějším růstem, tehdy však dosahovaným z mnohem nižši výchozi úrovně systémů (Pernica, 2006). 


\section{Věci je třeba, ,dělat tam, kde je lze dělat nejlépe“6. Jaké jsou toho logistické limity?}

- Převedení výroby do země s nízkými náklady vyžaduje celkový pohled na problém ve všech souvislostech, volbu správného výrobku, výběr vhodného zdroje, návrh logistického řetězce, modelové hodnocení výsledků, konečné rozhodnutí. Roste riziko a potřeba supply chain risk managementu. Mění se pohled na vhodnost logistických technologií.

Náklady nového logistického řetězce mohou převážit sniženi nákladů na výrobu a úroveň služeb zákazníkům na domácím trhu může utrpět. Existuji značná rizika ztráty duševního vlastnictví a sniženi kvality, riziko z outsourcingu hlavní činnosti. V úvahu přcházeji především výrobky, u nichž je kličovým faktorem cena, zralé, s předvídatelnou poptávkou, s vysokým podilem nákladů na práci, s jednoduchou montáži a s velkou přidanou hodnotou. Finální montáž a individualizaci výrobků je výhodné provádět co nejbliže k zákazníkům. Zvážit je třeba úroveň logistické infrastruktury dané země, spolehlivost dodavateli̊, účelnost outsourcingu výroby. U logistického řetězce musí být jasno $v$ otázkách jeho vybavení, informačního systému, ř̀zení, propojení $s$ dodavateli, transparentnosti procesù, dodacich lhüt, zásob, nepravidelnosti, možností využití služeb mistnich poskytovatelü. Modelově je třeba prověrit celý integrovaný retězec, se zvláštním zřetelem $k$ zásobám odpovídajicim dodacím lhủtám a úrovni služeb zákazníkưm, $k$ finančni stránce. Konečné rěšeni může být podmíněno změnou výrobki či operaci určených k přesunutí do nizkonákladové zemé.

Přechod ke globální dimenzi logistických řetězců se citelně dotýká i logistických technologií: silně je problematizována nejrozšírenějšsi z nich, JIT, implementovaná ve snaze co nejvíce redukovat zásoby $v$ retězci. Složitost a potenciální zranitelnost dlouhých řetězců vede $k$ odklonu od konceptů typu „pipeline“ a k integraci zásob do retězců a jejich umistováni do logistických center a skladů, včetnè nárazníkových skladů v blízkosti výrobních či montážních kapacit. Dalším di̊vodem $k$ těmto krokům je nedostatek kapacit na některých námořnich trasách, predevšim přetižené přistavy. Námořni doprava se vyrovnává s boomem, jenž v její historii nemá obdobu, vyvolaným expanzi mezikontinentálních logistických operací, smérovaných zejména na Č́nu. (Námořní doprava - dálná plavba - zaujímá 1. místo s cca $70 \%$ ve fyzickém objemu zahraničního obchodu EU - ve vývozu a dovozu mimo EU.) Limitujicím faktorem je i letecká nákladní doprava, a to kvůli časovým nejistotám $v$ důsledku bezpečnostních opatření, povětrnostnich vlivů i kvůli vysokým cenám. (Podíl letecké dopravy na fyzickém objemu zahraničního obchodu EU-vývozu a dovozu mimo EU-činícca $12 \%$ a staví ji na 2. misto.) Růst zásob vyvolaný globalizačnimi posuny v logistických řetězcích je pozorován ve všech zemích, jež se globalizace účastní; napřiklad v USA byl mezi lety 2003-2005 téměr 9\% a hodnota zásob tam v loňském roce dosáhla 1,6 mld. USD. Zároveň je důrazněji než dřive presouvána odpovédnost za dodávky, včetně udržování a financováni zásob, z odběratelů na dodavatele.

- Zásadním problémem uvnitř evropského subkontinentu je udržitelná mobilita.

Mobilita osob a zboži je součástí svobody pohybu a svobody podnikání a je tudíz prakticky neomezitelná. S rostoucí životní úrovni se však zvyšuje tempem, jež hrozi kolapsem dopravy $i$ životního prostředí. Zatímco v letech 1991-2000 byl reálný rưst HDP v EU-15 2,1\%, výkony v nákladni dopravě (v tkm) rostly o 2,9\%. V letech 2000-2005 se průmèrný růst HDP zpomalil na 1,8\%, avšak výkony v nákladni dopravě rostly o 2,8\%. Posledni scénáře EK počitají s ruistem HDP v obdobi 2000-2020 meziročněo $2,1 \%$-celkem o $52 \%$ a s rùstem výkonů v nákladní dopravěo $50 \%$, z toho 
v silniční nákladní dopravě o $55 \%$ a v železniční nákladní dopravě o $13 \%$. Podíl silniční dopravy na přepravě zboži je v současné době $44 \%$ (a stoupá), podíl na spotřebě energie je 25,2\%. Podil železnični dopravy na přepravě zboži je $10 \%$ (klesá), na spotřebě energie 0,8\%. Hlavni problém uvnitř oboru dopravy - nevyváženost rozvoje jednotlivých druhů dopravy pưsobicí kongesce na silničních tazich a ve městech - se nedař́ ř řsit. $V$ di̊sledku toho se prohloubily negativní účinky dopravy na životní prostředí: škody se odhaduji na 1,1\% HDP, z toho na dopravní kongesce připadá $1 \%$ HDP (Bílá kniha dopravy, 2005).

- Velká část nákladní dopravy $\mathrm{v}$ evropských podmínkách není nezbytně nutná a je důsledkem neregulované mobility zboží a špatných logistických strategií vedoucích k přepravám zboží na velké vzdálenosti bez objektivních důvodů.

Připomeňme analýzu Rakouského automotoklubu: prepravní náročnost běžných potravin tvořicich snidani Vídeňanů predstavuje v součtu na jednu snídani 5000 kilometrů. Pokud to budou i některé potraviny dovážené z jiných zemí EU, bude to až 10000 kilometrü, ujetých prevážně nákladními automobily. Konkrétně, např́klad u pečiva se přepravní vzdálenost změní z $20 \mathrm{~km} \mathrm{na} 600 \mathrm{~km}$, u jogurtĩ z $30 \mathrm{~km} \mathrm{na} 700 \mathrm{~km}$, u sýrù z $270 \mathrm{~km}$ na $700 \mathrm{~km}$ atd. Po vstupu Rakouska do EU se napřiklad u mléka prepravní vzdálenost ztrojnásobila (Pernica, 2005).

- Vstup země do EU má za následek skokový nárůst přepravy zboží. Ten je realizován převážně silniční dopravou.

$V$ době vstupu v roce 1986 mělo Španělsko HDP na jednoho obyvatele na úrovni $69 \%$ a Portugalsko 55 \% komunitárního průméru. V roce 1997 to bylo u Španělska již 78 \% a u Portugalska $71 \%$. Výměna zboží s ostatními zemémi EU během tohoto obdobi prudce stoupla ze 4,5\% na 13 \% ročné, zatímco průměrný nárůst prepravy zboži v EU byl $v$ této době 2,2\%. Př́značné je, že 95 \% této výměny zboži v EU zboži bylo realizováno právě silnični dopravou s jejím dopadem na choulostivé životni prostředí Pyrenejského poloostrova. Podobným vývojem procházi výměna zboži mezi SVE-10 a EU-15: jen za léta 1990-1997 vzrostla o 25\% ročně u dovozu a o 12 \% ročné u vývozu. Pokud jde o Českou republiku, začátkem roku 2004 prejelo české hranice cca 550 tisic kamionů měsíčné, na podzim téhož roku to bylo přes 800 tisíc kamionů a na počátku roku 2006 již dvojnásobek. Zatižení dopravní infrastruktury České republiky by měly odpovidat prostředky do ní vložené. Generální plán rozvoje dopravní infrastruktury $\check{C} R$ vyč́sluje potřebné investice pro léta 200-2013 ve výši 728 mld. Kč a částku na údržbu 171 mld. Kč; celková potřebná výše prostředkì se tedy bliží 1 bil. Kč. Je předpoklad, že Česká republika získá v letech 2007-2013 z evropských fondi̊ na rozvoj dopravní infrastruktury $161 \mathrm{mld}$. Kč, cožje rekordní suma, jež predstavuje téměr čtvrtinu v̌sech finančních prostředků určených pro Českou republiku. Z evropských fondů by mély těžit rovněž železnični koridory a uzly.

Model dopravy, jehož hodlaji země SVE-10 použit pro svůj rozvoj, se nebezpečně podobá modelu, který byl (nikoli bez úspěchu) pravidlem v poslednich čtyriceti letech $v$ zemich EU, ale jehož limity - z hlediska ekonomické efektivnosti spojení se spotřebou energie nebo s vlivem na životni prostředí - dosáhly kritických hodnot. Nemély by kopírovat ani americký model neomezované mobility a tím také neefektivně rostoucí spotřeby energie (Hourcade, 2000).

- Teoreticky vzato, nejschůdnější cestou $\mathrm{k}$ minimalizaci výkonů v silniční nákladní dopravě v evropských podmínkách je ,internalizace externalit“. V praxi však naráží na problémy.

„Polluter Pays Principle“, zahrnutí všech sociálních nákladi̊ a nákladi̊ na prevenci a nápravu škod na životním prostředí do ceny za dopravu, naráži na velké množství 
těžko ocenitelných účinkì. Existuji studie (Kageson, 1993), kvantifikující částku, k niž by se touto cestou dospělo. Cena za naftu použivanou v nákladní dopravě by vzrostla o 200-300\%; predstavuje-li průmérná cena pohonných hmot $18 \%$ z celkových dopravnich nákladù, a ty tvoř́ 2-3\% tržeb na konci logistického řetězce, potom by zvýšení ceny nafty vedlo $k$ ročnímu rüstu maloobchodnich cen o necelých $0,5 \%$. Efektem by byla redukce výkoni̊ v silnični nákladni dopravě v EU zhruba o $8 \%$ během 10 let. Zdánlivě značně radikální politika na ochranu životního prostředí by tedy měla jen relativně mírný dopad na evropské logistické řetězce. Průzkum mezi britskými výrobci (Mc Kinnon, 1994) ukázal, že ani strmý vzestup cen silnični nákladní dopravy by s největši pravděpodobností nezpůsobil žádnou významnou změnu v poptávce po dopravě: firmy byly dotázány, jak by reagovaly na 50\% vzestup cen nákladni dopravy na dlouhé vzdálenosti; jen cca $10 \%$ firem odpovědělo, že by je to primélo restrukturalizovat logistický systém a pouhých $6 \%$ firem by uvažovalo o nějakých dalších zmènách ve vztahu ke svým zákazníkưm nebo dodavatelům. Nevzrušivost firem byla opodstatněna tehdy existujicím potenciálem úspor v oblasti skladů: modelová analýza (Cooper, 1991) možností centralizace skladů a koncentrace skladové sítě na př́kladu redukce skladové sítě tvořené sedmi sklady na jediný sklad pro národní distribuci -vedla k poznatku, že náklady na pohonné hmoty by musely vzrüst o $250 \%$, aby vyvážily úspory plynoucí z redukce skladové sitě. Tento potenciál je však dnes již vyčerpán a náklady na dopravu vzrostly do té míry, že doprava se dostala do čela ve struktuř logistických nákladi̊ a je hlavním limitujicím faktorem. Např́klad náklady $v$ silniční nákladní dopravě v České republice vzrostly za posledních pět let o $20 \%$ (z toho režijni náklady o $30 \%$ ), přičemž ceny za přepravu se v dìsledku tvrdého konkurenčního prostředi spiše snižují. Dopravcưm tak nezbývá prakticky žádný prostor k úsporám, což se mj. projeví i vočekávaném nárůstu cen v silniční nákladní dopravě po zavedení mýtného, a to až o 15-20\%, s dopadem na zvýšení maloobchodních cen v rádu několika desetin procenta.

- Zatímco logistické teorie i praxe se soustřed'ují na zlepšování struktury a chování logistických řetězců vytvářených izolovaně jednotlivými podniky, zůstává takřka nevyužit obrovský potenciál skrytý ve vzájemných vztazích těchto řetězců.

Dosavadní vývoj spočival v uzavřeném, výlučném rèěení řetězců firmou, která se jím snažila získat výhodu před konkurenty v oboru. Navzájem izolované, pred konkurenty střežené logistické řetězce jednotlivých firem mohou být slad'ovány a optimalizovány pouze vnitřně, nikoliv mezi sebou navzájem. Někteři kritikové (Jones, Simons, 2000) poukazuji na plýtváni s tím spojené, které definují jako aktivity spotřebovávajicí čas a zdroje, za něž by zákazník nebyl ochoten zaplatit, pokud by měl jinou možnost. Řešením může být náhrada velkých specializovaných výrobních závodi̊ několika menšimi flexibilními, schopnými produkovat širši sortiment a jejich umistěni bliže mistům spotřeby, dále zámèna velkých firemnich distribučnich center za sit' veřejných logistických center, rozmistěných v prepravních vzdálenostech výhodnějšich jak vưči výrobním závodům, tak vi̊či mistům spotřeby; sit logistických center lze navzájem propojit jedním systémem dopravní obsluhy s dispečersky optimalizovaným provozem dopravního parku. Očekávanými efekty jsou dalši masivní redukce zásob, snižení výkonů obslužné dopravy, lepši využití dopravních kapacit, redukce počtu vozidel, snižení logistických nákladi̊ a omezení zátěže životního prostředí (Pernica, 2005).

- Základní příčina vývojových problémů - orientace na stupňování spotřeby hmotných statků a ekonomický růst - je mimo dosah logistického řešení a v praktické rovině zůstává zcela neřešena. 
„Mnohé procesy v naši technické civilizaci mají kruhovou podobu pozitivní zpětné vazby a lze je, když byly jednou uvedeny do chodu, těžko zastavit. Př́lkladem toho je hospodářrský růst a rostoucí potřeby konzumentů vyvolávané reklamou" (Lorenz, 1997). „Hlavní organizujicí silou společnosti se na Západě stala spotřeba ... Veškeré úsili kapitálu a prùmyslu dnes směruje $k$ tomu, aby vytvárelo zákazníky ... Hlavním faktorem hospodářské expanze je tvořeni nových potřeb. A prostřednictvím potřeb tvořeni nových spotřebitelü, nových zákazníkü“ (Bauman, 1999).

- Logistická pozice České republiky v Evropě: atraktivita spočívá v poloze ve střední Evropě, která zaručuje výkonný prístup k zákazníkům v celé Evropě s nízkými náklady a v kvalitě pracovní síly. Projevuje se na ní i systém investičních pobídek.

Podle ratingu Cushman \& Wakefield / Healey \& Baker je Česká republika již druhým rokem na 4. misté logisticky atraktivních zemí v rámci Evropy: v roce 2005 bylo pořadí: 1. Francie, 2. Německo, 3. Belgie, 4. ČR, v roce 2006: 1. Belgie, 2. Francie, 3. Nizozemsko, 4. ČR, (5. Polsko, 6. Německo). Hodnotila se dosažitelnost trhu, kvalita infrastruktury, dostupnost pracovnich sil a struktura nákladů. První vlna př́mých zahraničních investorü, která přišla do České republiky, dosáhla ve svých závodech dvojnásobnou produktivitu (produktivita $v$ automobilovém průmyslu je dokonce větš́i než v EU-15), vyšši efektivnost, větši vývozni výkonnost a intenzivnějšš využití služeb logistických poskytovatelů než domácí podniky, nepřinesla však vyšši technologickou náročnost produkce. Investice „na zelené louce“ byly umístěny u projektů se zvýhodněnými pobídkami z více než 55\% na východ od Prahy, resp. z téměr $18 \%$ do nejbližšiho okoli Prahy, z cca $46 \%$ na západ od Prahy; u ostatních projekti̊ to bylo na východ od Prahy $53 \%$, do okoli Prahy $27 \%$ a na západ od Prahy $32 \%$. V porovnáni s tím, sklady a logistická centra poskytovatelů logistických služeb se nacházejí pouze z $20 \%$ na východ od Prahy, ze $75 \%$ v nejbližšim okoli Prahy a z necelých $5 \%$ na západ od ní. Rozsáhlé části území republiky, např́klad kraje Vysočina a Jihočeský jsou logistickou infrastrukturou vybavené dosud nedostatečně.

V meziročním srovnání (k březnu 2006) vzrostla nejvice výroba dopravnich prostředki̊ a zařizení - o 38,4\%, což opět posílilo postavení Ceské republiky mezi výrobci automobilů a jejich dodavateli v rámci Evropy: po náběhu výroby v automobilce Hyundai bude Ceská republika na 5. mistè v počtu vyrobených automobilù (1,1 mil.) $v$ Evropě, v prepočtu na obyvatele na 2. mistě (108 vozůlobyvatele) za Slovenskem (152 vozůlobyvatele, se započtením plánované výroby Peugeot - Citroën a KIA). Do automobilového pri̊myslu také plynou největšsi prímé zahraniční investice v České republice: Toyota/PSA 29,8 mld. Kč, Hyundai 28,0 mld. Kč (předpoklad), Škoda Auto

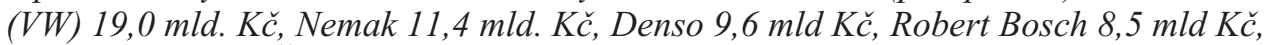
VDO 6,3 mld. Kč. Škoda Auto vyprodukovala v roce 2005492 tisice automobilů, závod TPCA v Kolíně a nošovický závod Hyundai maji montovat po cca 300 tisících automobilů ročně. Škoda Auto je největším vývozcem: na exportu České republiky se podili $8,2 \%$ - v roce 2005 vyvezla do zemí západni Evropy 276 tisíc automobilu a do zemi střední a východní Evropy 186 tisíc automobilů; na domácí trh dodala přes 65 tisic automobilü; je lídrem trhů v České republice, na Slovensku, v Bulharsku, v Bosně a Hercegovině a nové také v Polsku. Škoda Auto zaměstnává 22,5 tisíce pracovníki̊ (kmenový personál). Nový závod Hyundai má zaměstnat 3 tisíce osob, avšak u dodavatelì vznikne až 12 tisic pracovnich mist. Dodavatelské propojení vytvárí silné logistické vazby: podíl montážnich dílù vyrobených na území Ćeské republiky je u Škody Auto 25-75\%, u TPCA cca $50 \%$ a u Hyundai má být nejméně $65 \%$ (podle ČTK).

- Diskutovat lze budoucí možný problém nadbytku logistických kapacit po odchodu zahraničních investorů do levnějších zemí dále na východ. Druhá vlna přímých 
zahraničních investorů v oblasti technologií založených na znalostech a na vysoké přidané hodnotě nebude vytvářet masivní logistické řetězce ani potřebovat klasické zasílatelské a logistické služby v dnešním rozsahu.

Během 1. pololetí 2006 ztratila Česká republika pozici sedmé investorsky nejatraktivnějši evropské zemé (kterou zaujímala v roce 2005 se 45 realizovanými investičními projekty) a ocitla se mimo „Top Ten“. Totéž postihlo Slovensko, jež bylo na 10. místě. Pokles př́livu zahraničních investic se týká i Polska (nyni na 7. místě) a Mad'arska (10. místo). Zájem investorù se obrací k Bulharsku a Rumunsku, mimo Evropu k Č́né. Přesto se očekává, že v nových členských zemích EU a v dalších nových prümyslových zemich vznikne v letech 2005-2010 84\% z celkového počtu nových montážnich závodi̊ automobilových výrobců, přičemž v České republice má výroba automobilů do konce tohoto obdobi rüst nejrychleji (studie Ernst \& Young, PricewaterhouseCoopers).

\section{Jak se vývoj projevuje na logistickém trhu? Umí si firmy vybrat správného logistického partnera?}

- Evropský trh logistických služeb má obrat kolem 480 mld. EUR a narůstá. Trh vytvářejí především výrobci automobilů a potravinářské řetězce.V západní Evropě je roční růst logistického trhu 5,2 \%, trh v České republice má růstový potenciál $15 \%-20 \%$ ročně.

Výdaje na logistiku představují v Německu 6,4\% HDP a v USA cca $10 \%$ HD. Nárůst trhu logistických služeb je ovlivněn vyspělostí ekonomiky a rozvojem outsourcingu (65\% německých přepravců vidí v outsourcingu v zásadě správnou cestu). V Evropě mají prüměrné logistické náklady (vč. externich) Německo, Rakousko, Nizozemsko a Belgie. Nizozemsko a Belgie si udržuji postavení evropsky nejvýznamnějších tranzitnich zemí; to je dáno jejich vazbou na námornni dopravu. Jejich dopravní infrastruktura je na velmi dobré úrovni. Rovněž Německo je logistickým významným trhem s ročním obratem cca $166 \mathrm{mld}$. EUR, 60 tisíci logistickými firmami a 2,6 mil. pracovniků; jeho dopravní infrastruktura, zvláště dálniční, je však přetižená. Naproti tomu v Polsku je vyhovující pouze 0,5\% z celkové délky silniční a dálnični sitě.

- Většina průmyslových a obchodních firem outsourcovala jen malou část svých logistických činností. Největší rozsah outsourcingu je u distribuce.

Téměř $72 \%$ německých podniků outsourcovala logistické činnosti v rozsahu 10-40\%, necelých $84 \%$ podniku v rozsahu 10-50\%. Outsourcingu 50-60\% logistických činností dosáhla necelá $4 \%$ podniků a 60-70\% činností má outsourcováno ani ne 2,5\% podnikü. To svědči o dosavadním vývoji logistického trhu v neprospěch 4PL poskytovatelu․ Rozsah uplatněni outsourcingu je v distribuci $34 \%$, v opatřováni $29 \%$ a ve výrobě pouze $15 \%$ (Pernica, 2005).

- Velcí aktérí logistického trhu působí čím dál tím více globálně. K úspěchu je nutné, aby poskytovatel disponoval celosvětovou logistickou sítí. Poskytovatelé s agresivní strategií růstu dosahují až trojnásobného tempa růstu. Velikost poskytovatele ale není zárukou jeho ziskovosti.

Analýza vztahů mezi geografickým pokrytím a stupněm logistické specializace $u$ konkrétnich poskytovatelu logistických služeb ukazuje, že nejziskovějšimi jsou poskytovatelé s vysokou specializací při solidním, ne však nutně maximálním, geografickém pokrytí. Výsledek analýzy je dobré chápat ve vztahu ke kritériím uplatňovaným klienty při výběru poskytovatele. 
- Typické pověření útvarů logistiky $\mathrm{v}$ evropských firmách na operativní úrovni nepřekračuje hranice skladování, balení a expedice a dopravy. Na strategické úrovni dominuje koordinace se zákazníky a s dodavateli a zabezpečení procesní orientace.

Na operativní úrovni nedochází z roku na rok $k$ žádným významným změnám. Na strategické úrovni stojí za pozornost nárůst pověrení logistického útvaru volbou zásobovacích a odbytových cest a masivní nárůst pověrením ve vývoji výrobků a v tvorbě programů. Většina např. německých firem však chápe logistiku dost konzervativně, což znamená, že i nadále se ,rozevírají nůžky" mezi logisticky - a tudíz i konkurenčně - schopnými a méně schopnými podniky.

- Evropští poskytovatelé logistických služeb nabízejí hlavně vychystávání, kompletaci a balení, poradenství, služby přidávající hodnotu a skladování. V USA je nejčastěji outsourcována doprava, ověřování nákladních listů, platby a skladování či cross-docking. $V$ nabidce némeckých poskytovatelů (analýza BSL: 2160 poskytovatelů) dominuje vychystávání, kompletace a baleni (66\% poskytovateli), logistické poradenství (asi $49 \%$ poskytovateli̊), etiketování (48\%), centrální skladováni (39\%), rízení zásob (36\%) (Pernica, 2005).

- Ve srovnání s 90. lety roste spokojenost se službami poskytovatelů, s výhradou k jejich aktivitě, trvá tendence $\mathrm{k}$ dlouhodobější spolupráci, avšak smluvní vztahy jsou stále převážně krátkodobé, roste význam nákladových úspor a potvrzuje se význam vzájemné důvěry. Hlavním důvodem $\mathrm{k}$ rozchodu s poskytovatelem je jeho nespolehlivost.

Jako důvod ke změně poskytovatele uvádějí němečtí klienti 1. nespolehlivost, což obnáši předevšim pozdni a neúplné informace od poskytovatele, nepresnost jeho práce a nedodrženi slibu, 2. nepoměr mezi kvalitou a cenou jeho služeb ve srovnáni s konkurenčními poskytovateli. Podobně hodnotí britští klienti: 1. selhání poskytovatelových služeb, 2. špatná kvalita managementu poskytovatele, 3. nedostatečné informace, 4. nedostatečná flexibilita, 5. cena. Změna poskytovatele je však nákladnou záležitostí, jak uvádí $57 \%$ německých klientũ. Déle než 3 roky se svým poskytovatelem spolupracuje $80 \%$ klientù, déle než 5 let $55 \%$ klientů (Pernica, 2005).

- Mezi kritérii výběru 3PL poskytovatele dominují kompetence poskytovatele, dobré zkušenosti s ním, územní blízkost, jeho znalosti a osobní dojem z jeho pracovníků. Kritéria výběru 4PL jsou jiná: nejdůležitější je schopnost poskytovatele zformulovat strategii SC, provést reengieneering logistických procesů, technologickou integraci a racionalizovat oblast $\mathrm{HR}$.

Tvưrci konceptu 4PL ze společnosti Accenture odhadují, že nyní je pro uplatněni $4 P L$ př́znivá situace, nebot’ dosažení ziskovosti je podminěno rychlými a zásadními nákladovými úsporami, přičemž běžné př́ležitosti k nim jsou již vyčerpány. Nutností je však odklon od přiliš specifických modelù zaměřených na jednoho zákazníka a př́klon $k$,mnohonásobným zákaznickým modeli̊m“. Zásadně odlišný přistup však radí Pricewaterhouse Coopers Consulting, zdůrazňnjici význam Customer Relationship Managementu a nemožnosti jednoho logistického řešení, jež by vyhovovalo všem potřebám klientů. Posilení vazeb na zákazníka také praktikuje $89 \%$ německých poskytovatelì.

\section{Závěr}

Symptomy přechodu od industriální éry k éře informatiky se týkají logistiky do té míry, jak na logistických strategických a procesních schopnostech závisejí podniky $\mathrm{v}$ různých odvětvích. Všeobecně lze konstatovat rostoucí význam logistiky a posun $\mathrm{v}$ jejím 
chápání, ovlivňovaný vývojem směrem $\mathrm{k}$ individualizaci výroby, distribuce a spotřeby. Ten vede $\mathrm{k}$ polarizaci logistických strategií i k „rozevírání nůžek“ mezi podniky, podle toho, jak jsou jejich vrcholové managementy připraveny využít strategický potenciál logistiky. V ideálním př́padě se logistika stává stimulátorem vývojových změn.

Polarizace logistických strategií se promítá do polarizace logistických technologií. Logistické systémy směřují, spolu s výrobou, $\mathrm{k}$ flexibilitě, agilitě a štíhlosti a virtualizují se, čímž se stávají významným zdrojem konkurenční výhody. Dosavadní dominance nákladových úspor bude patrně $\mathrm{v}$ blízké budoucnosti vytěsněna dominancí pružnosti a dodavatelské kvality. To může vést $\mathrm{k}$ dalšímu vzestupu outsourcingu a jeho transformaci v partnering. S touto možností koresponduje růstový potenciál logistického trhu.

Postupující proces globalizace problematizuje tradiční logistické technologie, vhodné $\mathrm{u}$ řetězců $\mathrm{s}$ národní či regionální dimenzí. Rizika a náklady plynoucí z globálních logistických řetězců mohou převážit výhody z přesunu výroby do nízkonákladových zemí.

Konzumní orientace společnosti a prodlužující se přepravní vzdálenosti vedou k růstu v nákladní dopravě rychlejšímu než je růst HDP a doprava se stává limitujícím faktorem logistiky i životního prostředí.

Analýzy ukazují na existenci stále značného potenciálu logistiky, jenž je schopen přinášet masivní efekty v oblastech produktivity, zásob a výrobních a skladových kapacit. Nevyužit zatím zůstává potenciál ve vztazích mezi logistickými systémy jednotlivých podniků, jež vytváŕejí spolu se svými dodavateli, distribučními a obchodními partnery. Otázkou je budoucí potřeba fyzických logistických kapacit, jejichž rozvoj nyní prochází obdobím boomu, vzhledem k očekávaným strukturálním změnám ve prospěch odvětví založených na službách, přidané hodnotě a znalostech, spíše než na výrobě a distribuci hmotných statků.

\section{Literatura}

[1] BAUMAN, Z. 1999. Globalizace. Důsledky pro člověka. Praha: Mladá fronta, 1999, ISBN 80-204-0817-7.

[2] Bílá kniha dopravy. Hodnocení v poločase. Brusel : EK, 2005.

[3] COOPER, J. C. 1991. Innovation in Logistics: The Impact on Transport and the Environment. Freight Transport and Environment. Amsterdam, Elsevier, 1991.

[4] CHRISTOPHER, M. 2000. Logistika v marketingu. Praha : Management Press, 2000, ISBN 80-7261-007-4.

[5] HANSLÍČEK, P. 2005. E-logistika a české podniky. Disertační práce. Praha : Katedra logistiky, VŠE v Praze, 2005.

[6] HOURCADE, J. 2000. Do kdy je současná mobilita udržitelná? Vývoj relací mezi mobilitou a energií. Transports, 402/2000. In Informace ze zahranični dopravy, 3/2001, DATIS Praha.

[7] JONES, D. T., SIMONS, D. 2000. Towards Perfect Customer Fulfilment. Logistics Focus, 10/2000, ISSN 1466-836X.

[8] KAGESON, P. 1993. Getting the Prices Right: A European Scheme for Making Transport Pay its True Costs. Brusel, European Federation for Transport and the Environment, 1993. 
[9] KŘOVÁK, J. 2002. Nová ekonomika: sociálně ekonomické implikace, implikace pro statistiku. Politická ekonomie, 1/2002, ISSN 0032-3233.

[10] LORENZ, K. 1997. Odumírání lidskosti. Praha : Mladá fronta, 1997, ISBN 80-204-0645-X.

[11] McKINNON, A. C. 1995. Logistics and the Environment. Logistics Europe, 6/1995.

[12] PERNICA, P. 2001. Logistický management. Teorie a praxe. Praha, Radix, 1998, 2001, ISBN 80-86031-13-6.

[13] PERNICA, P. 2005. Logistika (Supply Chain Management) pro 21. století. Praha : Radix, 2005, ISBN 80-86031-59-4.

[14] PERNICA, P. 2006. Strategie logistiky a řízení logistických řetězců. In Nová teorie ekonomiky a managementu organizací. Sborník z mezinárodní vědecké konference. Praha : VŠE v Praze, 2006, ISBN 80-245-1091-X.

[15] TOFFLER, A, TOFFLEROVÁ, H. 2001. Nová civilizace. Třetí vlna a její důsledky. Praha : Nakladatelství Dokořán, , ISBN 80-86569-00-4.

\section{Quo vadis, logistica?}

\section{Petr Pernica}

Př́íspěvek odpovídá na otázky: Věci je třeba „dělat jinak“. Vyžaduje nová strategie také nové logistické technologie? Jsou nákladové úspory stále tak důležité? Jakých efektů lze dosáhnout logistickým řešením? Věci je třeba „dělat tam, kde je lze dělat nejlépe“. Jaké jsou toho logistické limity? Jak se vývoj projevuje na logistickém trhu? Umí si firmy vybrat správného logistického partnera?

Klíčová slova: logistika; logistická strategie; logistické technologie; poskytovatelé logistických služeb; globalizace; doprava a životní prostředí.

\section{Quo vadis, logistica?}

This abstract answers the following questions: "Is it necessary to do things differentia telly?", "Do new strategies express new technologies as well?", Are the cost savings still important?, "Which effects can be achieved by logistic solutions?", Things are necessary to where they can be done better?", "Which are limits of that?", "How does the development effects the logistic market?", "Could firms choose the right logistic partners?".

Key words: logistics; logistics strategy; logistics technology; logistics providers; globalisation; transport and environment. 